\title{
Habitat suitability for primate conservation in north-east Brazil
}

\author{
Bárbara Moraes, Orly Razgour, Joño Pedro Souza-Alves \\ JEAN P. BOUBLI and BRUNA BEZERRA
}

\begin{abstract}
Brazil has a high diversity of primates, but increasing anthropogenic pressures and climate change could influence forest cover in the country and cause future changes in the distribution of primate populations. Here we aim to assess the long-term suitability of habitats for the conservation of three threatened Brazilian primates (Alouatta belzebul, Sapajus flavius and Sapajus libidinosus) through (1) estimating their current and future distributions using species distribution models, (2) evaluating how much of the areas projected to be suitable is represented within protected areas and priority areas for biodiversity conservation, and (3) assessing the extent of remaining forest cover in areas predicted to be suitable for these species. We found that $88 \%$ of the suitable areas are outside protected areas and only $24 \%$ are located in areas with forest cover. Although not within protected areas, $27 \%$ of the climatically suitable areas are considered priority areas for conservation. Future projections, considering a severe climate change scenario, indicate that A. belzebul, S. flavius and S. libidinosus may lose up to 94,98 and $54 \%$ of their suitable range, respectively. The establishment of primate populations and their long-term survival in these areas are at risk. Mitigation actions such as the implementation of new protected areas, forest restoration and reduction of greenhouse gas emissions will be essential for the conservation of Brazilian primates.
\end{abstract}

Keywords Brazil, climate change, future range shift, gap analysis, primates, priority areas, protected areas, species distribution models

Supplementary material for this article is available at doi.org/10.1017/So030605319001388

Bárbara Moraes (Corresponding author, (10) orcid.org/0000-0002-1804-9828), Joāo Pedro Souza-Alves (두) orcid.org/0000-0002-8517-1276) and Bruna BezerRa (잉 orcid.org/0000-0003-3039-121X) Programa de Pós-Graduação em Biologia Animal, Departamento de Zoologia, Centro de Biociências, Universidade Federal de Pernambuco, Av. Prof. Moraes Rego, 1235 Cidade Universitária, Recife PE, 50670-901, Brazil

E-mail barbaralcm151@gmail.com

OrLy RazGouR* (ㅁ orcid.org/0000-0003-3186-0313) Biosciences, University of Exeter, Exeter, UK

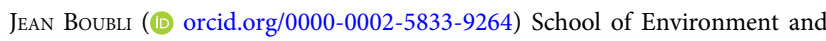
Life Sciences, University of Salford, Salford, UK

*Also at: Biological Sciences, University of Southampton, Southampton, UK

Received 18 May 2019. Revision requested 16 July 2019.

Accepted 11 November 2019. First published online 28 September 2020.

\section{Introduction}

$\mathrm{B}$ razil is home to 115 species of non-human primates B (Estrada et al., 2017; Costa-Araújo et al., 2019; IUCN, 2019), of which 21 occur in the Atlantic Forest, Cerrado and Caatinga biomes in the north-east. These three biomes have been extensively modified by centuries of anthropogenic forest destruction for the development of agriculture, infrastructure and urban areas. Primate populations are in sharp decline, including the most charismatic, elusive and rare species. Half of the primate species in north-east Brazil are under threat, including five species categorized as Endangered and five categorized as Critically Endangered on the IUCN Red List of Threatened Species (IUCN, 2020). Although much attention has been, rightfully, devoted to the plight of the Brazilian Atlantic Forest, there has been little focus on the Cerrado and Caatinga. The Caatinga in particular has been neglected in terms of conservation action, although nearly half has already been lost (Beuchle et al., 2015). It is predicted that the Atlantic Forest, Cerrado and Caatinga biomes will be severely affected in the future by continuing anthropogenic impacts in these rapidly developing areas, and by climate change (Marengo et al., 2017). Thus it is important to determine which areas will be more severely affected and where new protected areas are required to create an effective network of protected areas that supports the future survival of primates in these biomes (Estrada et al., 2018).

In 2011 the Instituto Chico Mendes de Conservação da Biodiversidade, the national institution for biodiversity conservation in Brazil, developed a conservation action plan for the primates of north-east Brazil (ICMBio-CPB, 2018). Six of the 21 primate species in the area were included in this conservation action plan: the red-handed howler monkey Alouatta belzebul, Caatinga howler monkey Alouatta ululata, blonde titi monkey Callicebus barbarabrownae, Coimbra-Filho's titi monkey Callicebus coimbrai, blonde capuchin Sapajus flavius and yellow-breasted capuchin Sapajus xanthosternos. These species occur in one or more of the three biomes occurring in north-east Brazil, the Atlantic Forest, Cerrado and Caatinga. The main threats to these primates are habitat destruction and fragmentation, hunting and the pet trade (ICMBio, 2016; ICMBio-CPB, 2018). One of the actions proposed in the conservation action plan is to determine more accurately the current distribution of all six species and to evaluate how these distributions will be affected by future human activities and climate change (ICMBio-CPB, 2018). Such data are essential 
for conservation planning, to ensure there is sufficient suitable habitat for the survival of these species through creating new protected areas, connecting existing ones and restoring key habitats.

Spatial analyses such as species distribution models and gap analyses are useful for assessing the impact of habitat loss and fragmentation on species (Beuchle et al., 2015; Titeux et al., 2017; Zwiener et al., 2018). Distribution models project potentially suitable areas for a particular species based on presence location records and abiotic environmental data (Elith \& Leathwick, 2009). Gap analysis assesses whether species or ecosystems are represented within existing protected areas; i.e. it identifies potential conservation gaps (Rodrigues et al., 2004). Both techniques provide information to guide efficient management actions for the conservation of a greater number of species (Rodrigues et al., 2004), and, if integrated, improve the interpretation of impacts of global change scenarios on biodiversity (Titeux et al., 2017). The combination of such approaches is thus important for conservation planning, particularly because research and conservation efforts have traditionally focused on charismatic species and protected areas, leaving some species and their habitats at high risk of extinction (Bezanson \& McNamara, 2019).

Here we combine species distribution models and gap analysis to assess the long-term suitability of habitats for the conservation of two of the six target species included in the conservation action plan: A. belzebul and S. flavius. We also include a third species, the bearded capuchin Sapajus libidinosus. This species is not included in the national action plan but is strongly affected by habitat loss (Beuchle et al., 2015; Rylands \& Kierulff, 2015), the illegal pet trade (Nascimento et al., 2013) and hunting for use in traditional medicine and in retaliation for crop use (Torres Junior et al., 2016; Freire-Filho et al., 2018; Souto et al., 2018). We chose these three species because their habitats represent the main biomes of north-east Brazil and they could thus serve as flagship species, with their protection providing wider benefits for the conservation of these habitats and other wildlife within them. We (1) estimate the current potential range of each species and project the effects of future climate change on their ranges, (2) evaluate the extent of suitable areas that overlap with existing protected areas and proposed priority areas for biodiversity conservation, and (3) assess how much forest cover still remains in the areas predicted as suitable for the occurrence of these species.

\section{Study area and species}

The study area comprises the known distribution area of the three target species, the Caatinga, Cerrado, Amazon and Atlantic Forest biomes, encompassing mainly the north-east of Brazil, but also areas in the north and in the centre-west (Fig. 1). The Atlantic Forest in north-east Brazil is at low altitudes $(400-800 \mathrm{~m}$; Tabarelli et al., 2010) with annual rainfall of $1,800-2,000 \mathrm{~mm}$ (Rêgo \& Hoeflich, 2001). The Caatinga and the Cerrado biomes are semiarid environments, with annual precipitation of $250-$ 1,200 mm (Ratter et al., 1997; Prado, 2003) and 750-2,000 mm (Hunke et al., 2014), respectively. Annual precipitation in the Amazon rainforest biome is 2,000-3,664 $\mathrm{mm}$ (Villar et al., 2009).

Alouatta belzebul has a disjunct distribution, occurring in the north-eastern Atlantic Forest and lower eastern Amazon in the Brazilian states of Amapá, Pará and Maranhão (Veiga et al., 2008). It is folivorous-frugivorous (Pinto et al., 2013) and categorized as Vulnerable on the IUCN Red List because its population has declined by $30 \%$ over 30 years (Veiga et al., 2008). It is estimated that the population restricted to the Atlantic Forest has only 200 individuals (Veiga et al., 2008).

Sapajus flavius occurs in the Atlantic Forest and Caatinga of north-east Brazil (Martins et al., 2016; Valença Montenegro et al., 2020). This species has a generalist diet (de Souza \& Ferreira, 2019; Medeiros et al., 2019) and is categorized as Endangered on the IUCN Red List because of habitat loss and fragmentation resulting from coastal development and sugar cane plantations (Valença Montenegro et al., 2020). It is recognized as one of the most threatened primates globally (Mittermeier et al., 2012), although it is no longer included in the list of the top 25 most endangered primate species (Schwitzer et al., 2019).

Sapajus libidinosus inhabits dry forests in semiarid areas, including the Caatinga and Cerrado biomes (Rylands \& Kierulff, 2015). Although categorized as Least Concern on the IUCN Red List (Rylands \& Kierulff, 2015), the Brazilian government considers it to be Near Threatened (ICMBio, 2016) and it is likely to become more threatened because of habitat loss (Beuchle et al., 2015; Rylands \& Kierulff, 2015) and illegal pet trade (Nascimento et al., 2013).

\section{Methods}

\section{Species distribution modelling}

We obtained occurrence data for the three target species from the Global Biodiversity Information Facility (2017) and speciesLink (2017). We also retrieved location records from the literature using the search terms Sapajus, Sapajus libidinosus, capuchin monkeys, Cebus, Cebus libidinosus, flavius, Cebus flavius, Alouatta, Alouatta belzebul, guariba, bugio, bugio-de-mãos-ruivas, macaco-prego, macaco-prego-galego, macaco-prego-da-caatinga, red-handed howler monkey, howler monkey, blonde capuchin monkey, and bearded capuchin monkey in ScienceDirect (Elsevier, Amsterdam, 


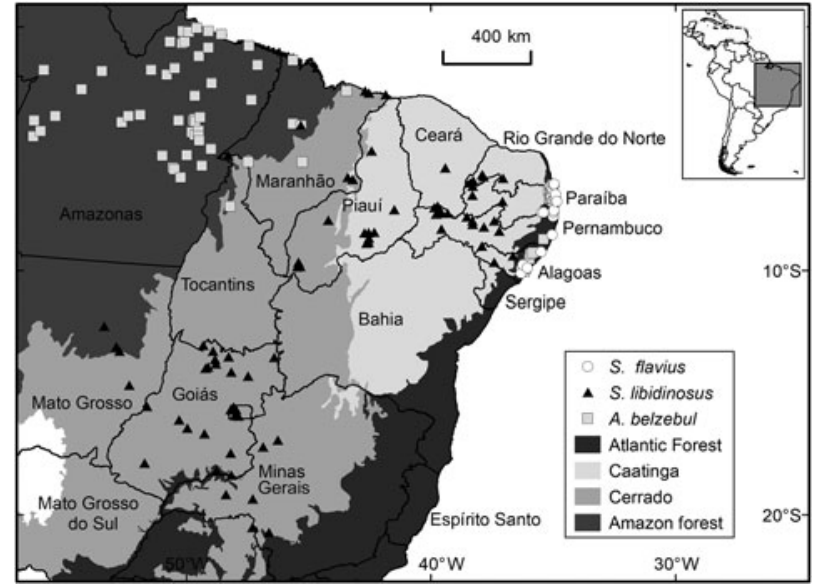

FIg. 1 Occurrence records for Alouatta belzebul, Sapajus flavius and Sapajus libidinosus in the biomes and the Brazilian states included in our study area.

The Netherlands), Web of Science (Clarivate Analytics, Philadelphia, USA), Periódicos CAPES (Coordenação de Aperfeiçoamento de Pessoal de Nível Superior, Brasilia, Brazil) and Google Scholar (Google, Mountain View, USA). We also collected new location data for S. libidinosus during 10 expeditions to nine localities in the state of Pernambuco, Brazil, during May 2016-March 2017. All records were validated using Google Earth satellite maps (Google, Mountain View, USA) to exclude records outside forested areas, which were probably the results of inaccurate coordinates.

We generated species distribution models with MaxEnt 3.4.1 (Phillips et al., 2006). This tool uses a maximum entropy algorithm to select environmental variables that explain species distribution using presence-only data (Phillips et al., 2006). The background was delimited, for each species, as a buffer of $500 \mathrm{~km}$ generated around the minimum convex polygon of all known occurrence records (Supplementary Fig. 1). We obtained climatic variables from WorldClim 1.4 (Hijmans et al., 2005), Brazil ecoregions (MMA, 2003) and geomorphology databases (INPE, 2001), and generated the slope layer from the altitude layer (Diva-GIS, 2011). To avoid collinearity, we only included variables that were not highly correlated ( $r<0.8$; Supplementary Table 1). Through principal component analysis (Supplementary Table 2) we selected the most important variables to include in each species' model. These variables explained $80 \%$ of the distribution models. All variables were downloaded at (or converted to) a resolution of 30 arc-seconds (c. $1 \mathrm{~km}^{2}$ ), which was the cell size for the analyses, using ArcGIS 10.1 (Esri, Redlands, USA).

We reduced spatial autocorrelation among location records through an environmental heterogeneity rarefaction analysis using SDMTools box (Brown, 2014) in ArcGIS. We created a buffer of $10 \mathrm{~km}$ around each occurrence record and randomly removed duplicate points within the zones of the buffers. We retained records that were within the same buffer but in pixels with different environmental characteristics. This procedure was performed to avoid a sampling bias, whereby clusters tend to give greater weight to environmental variables (Renner et al., 2015).

Models were projected into the future (2070) based on 13 general circulation models used in the 5th Intergovernmental Panel on Climate Change (IPCC) report (Flato et al., 2013): ACCESS1-o, HadGem2-ES, Miroc-ESM, BCC-CSM1-1, CCSM4, CNRM-CM5, GFDL-CM3, GISSE2-R, INMCM4, IPSL-CM5A-LR, MPI-ESM-LR, MRI$\mathrm{CGCM}_{3}$ and NorESM1-M. We selected the 2070 scenarios, which predict climate towards the end of the century, because predictions based on shorter time frames would not provide an adequate parameter representation of the impact of climate change on the species. We considered two representative concentration pathways, defined by the trajectory of greenhouse gas emissions and subsequent radiative forcing (Wayne, 2013): $4.5 \mathrm{~W} / \mathrm{m}^{2}$ (moderate climate change scenario) and $8.5 \mathrm{~W} / \mathrm{m}^{2}$ (severe climate change scenario). We converted the continuous model output into binary maps using the thresholding method, which maximizes the sum of sensitivity and specificity (Liu et al., 2013). To incorporate model variability while avoiding biases resulting from outlier model outputs we generated the final future maps for each scenario based on agreement between $>75 \%$ of the Maxent general circulation models outputs (upper quantile). This was done using ArcGIS, by adding the binary model outputs generated from the 13 general circulation models and reclassifying the resulting map, assigning a value of o (unsuitable) to cells that were identified as suitable by no more than three models, and 1 (suitable) to cells identified as suitable by more than three models.

We ran models with 1,500 interactions using the cloglog model output. We used the ENMeval package in $R$ 3.4.3 (R Core Team, 2017) to evaluate and select the best model parameterization (regularization multiplier value and number of parameters) based on the Akaike information criterion corrected for small sample sizes (AICc; Muscarella et al., 2014). The best fit model included three features (linear, quadratic and hinge) and a regularization multiplier of 1 . We evaluated the performance of the models using 10-fold cross-validations and the area under the receiver operator curve (AUC), a measure of the ability of the model to distinguish between presence locations and background/pseudoabsences. We compared model AUC scores with 100 null models, generated through resampling the isothermality layer in ENMTools (Warren et al., 2010), to determine whether our models performed significantly better than random (Raes \& ter Steege, 2007).

\section{Gap analysis}

We carried out gap and range change analyses using the reclassified binary maps. We calculated the representation of 
TABLE 1 Results of the species distribution models for the three studied primates, number of location records included in the models (N), results of the statistical tests used to evaluate model discrimination ability (area under the receiver operator curve; AUC) for training and test datasets and the per cent contribution of the different environmental variables.

\begin{tabular}{|c|c|c|c|c|c|c|c|c|c|c|c|c|}
\hline \multirow[b]{2}{*}{ Species $(\mathrm{N})$} & \multirow[b]{2}{*}{ AUC train } & \multirow[b]{2}{*}{ AUC test } & \multicolumn{10}{|c|}{ Environmental variables contribution $(\%)^{1}$} \\
\hline & & & Bio2 & Bio3 & Bio8 & Bio11 & Biol2 & Bio15 & Bio18 & Slope & Eco & Geom \\
\hline Alouatta belzebul (66) & 0.91 & 0.87 & 21.30 & 6.41 & & 3.97 & 10.76 & 7.97 & 0.43 & 3.68 & & 45.42 \\
\hline Sapajus flavius (33) & 0.98 & 0.97 & 0.69 & 7.78 & 0.15 & 1.65 & 37.46 & & 13.75 & 3.08 & & 35.41 \\
\hline Sapajus libidinosus (77) & 0.88 & 0.82 & 4.48 & 0.06 & & 0.36 & 3.30 & 9.10 & & 6.95 & 60.52 & 15.19 \\
\hline
\end{tabular}

${ }^{1}$ Bio2, mean diurnal range (mean of the difference of the monthly maximum and minimum temperatures over 1 year); Bioz, isothermality; Bio8, mean temperature of wettest quarter; Bio11, mean temperature of coldest quarter; Bio12, annual precipitation; Bio15, precipitation seasonality; Bio18, precipitation of warmest quarter; Eco, ecoregion; Geom, geomorphology.

predicted current and future suitable areas for each species by overlaying in $\operatorname{ArcGIS}$ the outputs of our models with maps of Brazilian protected areas (ICMBio, 2017; MMA, 2018 b), priority areas for biodiversity conservation (MMA, 2018a) and forest cover (IBGE, 2017). To identify protected areas and priority areas that will retain climatic suitability in the future, we overlapped areas that were predicted to be suitable under both present and future conditions with existing protected areas and priority areas. We overlapped priority areas and protected areas with our modelled suitable areas to identify relevant locations for the expansion or creation of protected areas. We also identified protected areas that are likely to be under threat because of hunting and other anthropogenic impacts by overlapping model outputs with a human settlement map (IBGE, 2017).

To categorize the degree of protection of the areas predicted by our models to be suitable for the target species, we considered the following categories: high protection status (protected areas of integral protection, where human settlement is not permitted, but certain activities such as scientific research and ecotourism are); medium protection status (areas under permanent protection in which sustainable use of natural resources and human occupation are permitted); low protection status (protected areas in which human settlement and development are permitted as well sustainable use of natural resources); and unprotected (areas not formally protected).

Areas defined by the Brazilian government as priority areas for biodiversity conservation are areas where conservation efforts should be directed for the planning and implementation of actions such as the creation of protected areas, licensing, inspection, and promotion of sustainable use. We considered areas occupied by forests as those with trees $>5 \mathrm{~m}$ tall, including areas of dense, open, seasonal and mixed ombrophilous forest, as well as forested savannah, forested campinarana and mangroves (IBGE, 2017). We defined human settlements as areas characterized by urban use, structured by buildings and road systems, where nonagricultural artificial surfaces predominate (IBGE, 2017). This category includes cities, towns, roads, services and transport, power grids, communication infrastructure and associated land, areas occupied by industrial and commercial complexes, buildings (which may in some cases be located in periurban areas), Indigenous villages and mining areas.

\section{Results}

We found 223 occurrence records for the three target species, 176 of which were retained after validation. These comprised 66 records of A. belzebul, 33 of S. flavius and 77 of S. libidinosus (Supplementary Table 3 ).

All species distribution models were able to discriminate between true presence and pseudo-absences $\left(\mathrm{AUC}_{\text {test }}\right.$ range: 0.82-0.97; Table 1) and performed better than null models because they fell outside the range of AUC values generated from 100 null models $\left(\mathrm{AUC}_{\text {train }}\right.$ range: $0.61-0.80$ ). Geomorphology, annual precipitation and ecoregion were the main environmental variables affecting habitat suitability for the target species (Table 1). The model considering current conditions predicted suitable areas of $671,47,184$ and $1,059,360 \mathrm{~km}^{2}$ for A. belzebul, S. flavius and S. libidinosus, respectively (Table 2, Fig. 2). Our future models considering climate change predicted a reduction in the areas suitable for all species (Table 2, Fig. 3).

Gap analysis showed that only 24, 8 and $9 \%$ of the areas predicted to be suitable under current climatic conditions for A. belzebul, S. flavius and S. libidinosus, respectively, fall within existing protected areas (Table 3 , Fig. 4), and $72 \%$ of these areas are of low protection status. Approximately $88 \%$ of the areas predicted to be suitable are unprotected.

In our models, we overlapped areas predicted to be suitable for the occurrence of the three target species with government priority areas and forest cover layers. We found that $27 \%$ of the suitable areas for all three target species together fall within government priority areas for conservation (10\% in the Amazon forest, $10 \%$ in the Cerrado, $6 \%$ in the Caatinga and $1 \%$ in the Atlantic Forest). Only $24 \%$ of the suitable areas are currently forested $17 \%$ in the Amazon forest, $4 \%$ in the Caatinga, $2.5 \%$ in the Cerrado and $0.5 \%$ in the Atlantic Forest; Table 3). Binary maps of 
TABLE 2 Area predicted to be suitable for the target species $\left(\mathrm{km}^{2}\right)$, considering current conditions, and future (2070) conditions moderate (RCP 4.5) and severe (RCP 8.5) climate change emission scenarios, and including their geographical range and future range loss.

\begin{tabular}{lllll}
\hline Species & Range & Distribution models & Area predicted to be suitable $\left(\mathrm{km}^{2}\right)$ & Range loss $(\%)$ \\
\hline A. belzebul & Atlantic Forest, Amazon forest & Current & 671,135 & 80.36 \\
& & Future moderate & 131,792 & 93.94 \\
S. flavius & \multirow{2}{*}{ Atlantic Forest } & Future severe & 40,607 & 77,184 \\
& & Current & 10,331 & 78.00 \\
S. libidinosus & Caatinga, Cerrado & Future moderate & 1,102 & 97.66 \\
& & Future severe & $1,059,360$ & 31.38 \\
& & Current & 726,892 & 54.00 \\
\hline
\end{tabular}
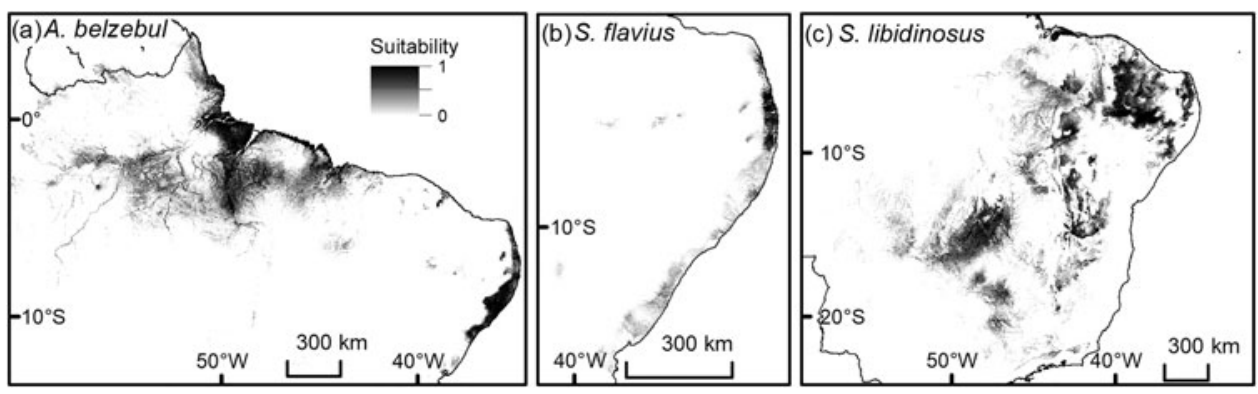

FIG. 2 Predicted current distribution of suitable areas for the occurrence of (a) A. belzebul, (b) S. flavius and (c) S. libidinosus. Suitability ranges from low (o) to high (1). current predictive distribution with their priority areas and forest cover are detailed in Supplementary Figs 2 and 3, respectively.

To identify relevant areas for the expansion or creation of protected areas, and potential connectivity between suitable areas, we overlapped government priority areas and protected areas with our modelled suitable areas. We found that 96,99 and $74 \%$ of the government priority areas within A. belzebul, S. flavius and S. libidinosus suitability areas, respectively, are outside protected areas (Supplementary Table 4).

Our analysis showed that $23 \%(93), 11 \%$ (43) and $73 \%$ (295) of protected areas will maintain climatic suitability under the moderate future climate change scenario for $A$. belzebul, S. flavius and S. libidinosus, respectively. These numbers decrease to $12 \%(50), 3 \%$ (13) and $67 \%$ (270) when we consider the more severe future scenario (see Supplementary Table 5 for a list of protected areas). Of all the protected areas identified as climatically suitable for the three primate species under present and future conditions, 14\% (56) overlap with human settlements. For S. flavius, in particular, $33 \%$ of climatically suitable protected areas overlap with human settlements (Supplementary Table 5). We also identified that $18 \%(91), 2 \%(12)$ and $88 \%$ (441) of government priority areas will remain climatically suitable under the moderate future climate change scenario for A. belzebul, S. flavius and S. libidinosus, respectively. These numbers decrease to $5 \%$ (25), $0.4 \%$ (2) and 61\% (357) when we consider the more severe future scenario (see Supplementary Table 4 for a list of government priority areas and conservation actions for each area).

\section{Discussion}

Our findings indicate concern for the future of A. belzebul, S. flavius and S. libidinosus, as $88 \%$ of the areas predicted to be suitable for these species are unprotected. The remaining $12 \%$ of the suitable areas fall within protected areas, but $72 \%$ of these have low protection status. Only $27 \%$ of the overall areas predicted to be suitable for the three species overlap with priority areas for conservation, and only $24 \%$ are currently forested. Future models predict a near total loss of climatic suitability for the three species in tropical forests (Amazon and/or Atlantic Forest) and loss of a quarter of suitable areas in the semiarid regions (Caatinga and Cerrado).

Our models were able to distinguish between the habitats of the three species. We found that habitat suitability is affected by geomorphology, annual precipitation and ecoregion, which together influence vegetation structure and composition (Shi-kui et al., 2019). Characteristics such as temperature variation and deciduous and semideciduous vegetation differentiate the species' habitat needs from those of other primates (Ratter et al., 1997; Prado, 2003). Water availability and changes in soil composition also play an important role by controlling the type of vegetation that can grow in different landscapes (El-Keblawy et al., 2015; Cowles et al., 2018). 
(a)

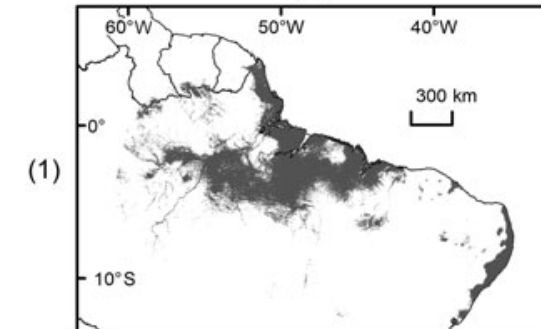

(2)

(3)

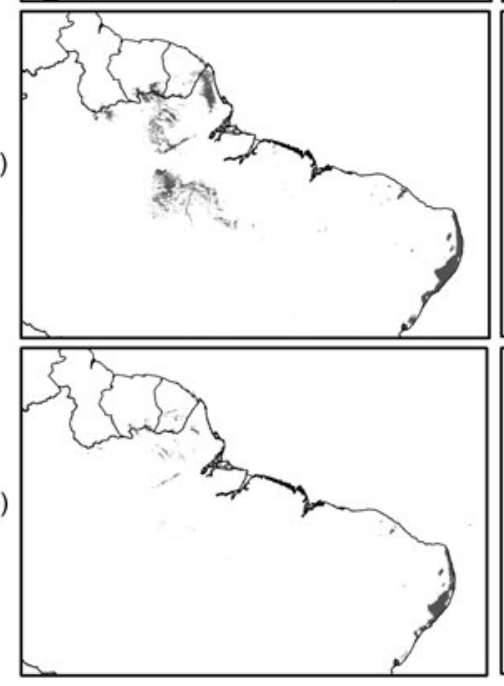

(b)

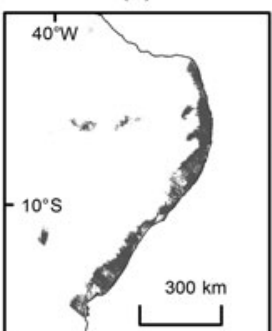

(c)

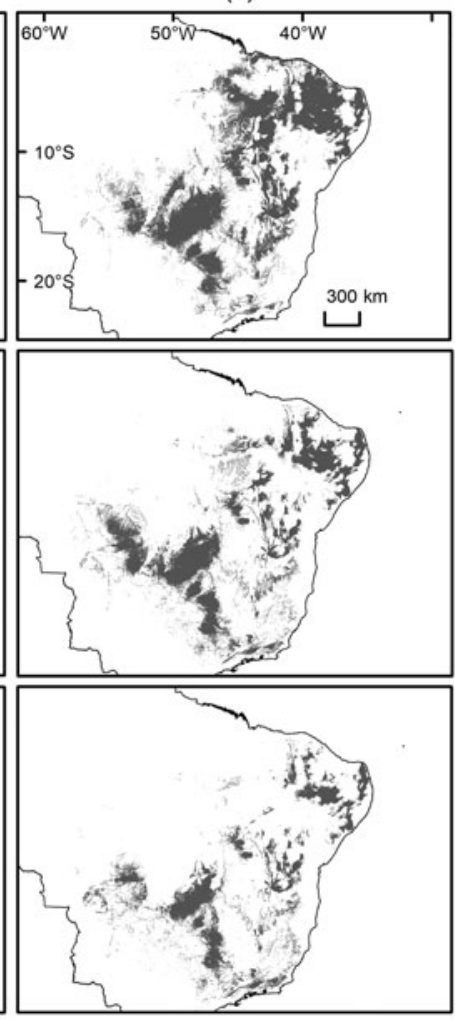

FIG. 3 Binary maps of present and future predictive distribution for (a) A. belzebul, (b) S. flavius and (c) S. libidinosus, under (1) current conditions, and future conditions under scenarios of (2) moderate (2070, RCP 4.5) and (3) severe (2070, RCP 8.5) climate change. Future predictions are based on 13 general circulation models for each scenario. Shaded areas indicate predicted suitable habitats above the maximum training sensitivity plus specificity threshold.
Our findings reflect the current situation of the protected areas system in Brazil, with a large proportion categorized as low protection status. Currently, only $10 \%$ of the Atlantic Forest is under protection and only $2.6 \%$ falls within the high protection status (MMA, 2018b). There is even less protection for the Caatinga and Cerrado biomes, with $8 \%$ of each protected and only 1.6 and $3 \%$, respectively, within the integral protection areas (MMA, 2018b). In contrast, $28 \%$ of the Amazon falls within protected areas and $9 \%$ within integral protection areas (MMA, 2018b). In areas with low protection status, extractive activities are permitted in accordance with applicable law, resulting in inadequate protection for species at imminent risk of extinction (Schulze et al., 2018). In addition, some areas officially designated as protected lack essential infrastructure or resources, resulting in little if any actual protection (Saout et al., 2013; Oliveira \& Bernard, 2017). Despite problems related to the poor management of these areas, protected areas are relevant because they prevent the conversion of natural ecosystems (Geldmann et al., 2013) and support a greater diversity and abundance of species than unprotected areas (Gray et al., 2016).

We observed the least overlap between habitat suitability for the primate species and government priority areas for biodiversity conservation in the north-eastern Atlantic Forest. This is because most of the Atlantic Forest priority areas are concentrated in southern Brazil (MMA, 2018a).
Only two government priority areas were considered in north-east Brazil and these are located in the state of Bahia, in areas where the target species do not occur. Although government priority areas cover c. $25 \%$ of biomes such as the Amazon, Caatinga and Cerrado, only 6-10\% of these areas were predicted as suitable for the three primate species in our study. Nevertheless, because a large proportion of government priority areas within the modelled suitable areas is not within protected areas, it will be necessary to identify potential connectivity areas, and areas for the expansion or creation of new protected areas, to conserve these primate species. The government priority areas within the areas suitable for the target species that will remain suitable under future climate change (Supplementary Table 4) are potential sites for reintroducing confiscated individuals from the illegal wildlife trade, provided these areas are under some level of legal protection.

The low forest cover in areas predicted to be suitable for the three target species is mainly a result of the high anthropogenic impact on biomes such as the Atlantic Forest, Caatinga and Cerrado. The north-eastern Atlantic Forest is highly fragmented (Ribeiro et al., 2011), and in the Pernambuco Endemism Center, which includes the distribution of A. belzebul and S. flavius, $99 \%$ of the remnant forest fragments are smaller than 50 ha (Silva \& Fialho, 2013). Similarly, only $50 \%$ of the original vegetation remains in the Caatinga and Cerrado (MMA, 2016; Strassburg et al., 2017). 
TABLE 3 Area predicted to be suitable for occurrence of the three primates and their representation in areas with different protections status (high, medium, low and unprotected), in priority areas for biodiversity conservation and in areas with forest cover.

\begin{tabular}{|c|c|c|c|c|c|c|c|c|c|c|c|c|c|}
\hline \multirow[b]{3}{*}{ Species } & \multirow{3}{*}{$\begin{array}{l}\text { Predicted suitable } \\
\text { area }\left(\mathrm{km}^{2}\right)\end{array}$} & \multicolumn{4}{|c|}{ Protection status (\%) } & \multirow{2}{*}{\multicolumn{4}{|c|}{$\begin{array}{l}\text { Priority area for biodiversity } \\
\text { conservation (\%) } \\
\text { Biome }^{1}\end{array}$}} & \multirow{2}{*}{\multicolumn{4}{|c|}{$\frac{\text { Forest cover area (\%) }}{\text { Biome }^{1}}$}} \\
\hline & & \multirow[b]{2}{*}{ High } & \multirow[b]{2}{*}{ Medium } & \multirow[b]{2}{*}{ Low } & \multirow[b]{2}{*}{ Unprotected } & & & & & & & & \\
\hline & & & & & & $\mathrm{AF}$ & $\mathrm{AM}$ & CA & $\mathrm{CE}$ & $\mathrm{AF}$ & $\mathrm{AM}$ & $\mathrm{CA}$ & $\mathrm{CE}$ \\
\hline A. belzebul & 67,1135 & 4.56 & 8.03 & 11.80 & 75.61 & 0.27 & 25.39 & 0.98 & 0.44 & 0.28 & 41.93 & 0.49 & 0.76 \\
\hline S. flavius & 47,184 & 0.44 & 0.48 & 7.13 & 91.95 & 1.76 & & 8.07 & & 6.61 & & 1.70 & \\
\hline S. libidinosus & $1,059,360$ & 2.32 & 0.35 & 6.75 & 90.58 & 1.09 & 0.80 & 10.12 & 15.22 & 0.57 & 1.29 & 6.17 & 3.88 \\
\hline
\end{tabular}

${ }^{1}$ Biomes: AF, Atlantic Forest; AM, Amazon forest; CA, Caatinga; CE, Cerrado.
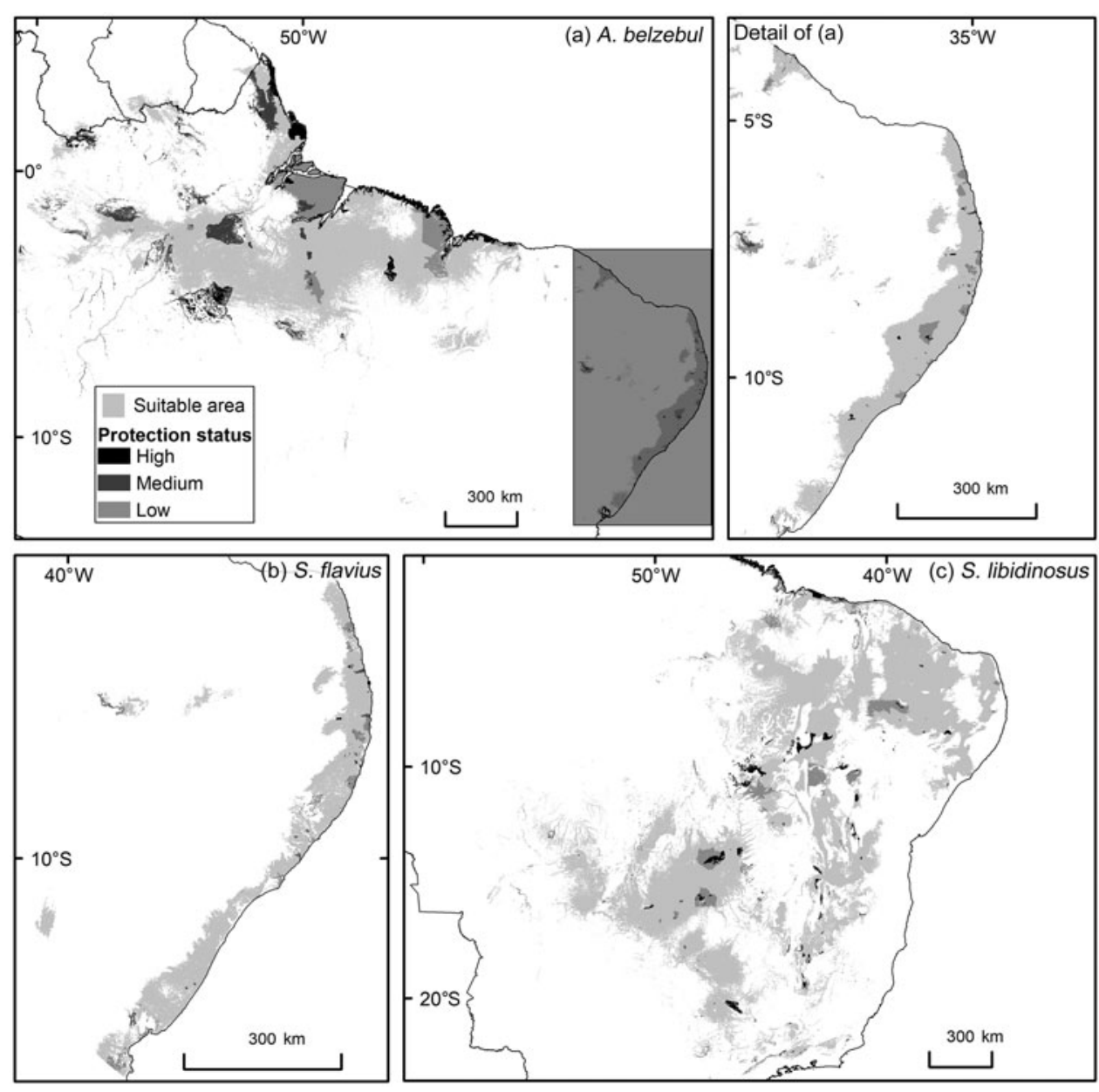

Fig. 4 Predicted suitable areas for the occurrence of (a) $A$. belzebul, (b) S. flavius and (c) S. libidinosus, and their overlap with protected areas of high, medium and low protection status.
In addition, habitat remnants within the Atlantic Forest and semiarid zones are surrounded by an inhospitable agricultural matrix that presents a barrier to movement and dispersal (Portillo-Quintero \& Sánchez-Azofeifa, 2010; Ribeiro et al., 2011). Areas of occurrence of $S$. flavius are also affected by mining (e.g. Bezerra et al., 2014). Although some primate species are able to cross and benefit from non-forested matrices, such as agricultural areas (Mandujano et al., 2004; Canale et al., 2013; Souza-Alves et al., 2019), this brings them into closer contact with people, potentially increasing negative human-wildlife interactions. Primates are threatened by dogs, contact with electrical wires, the illegal pet trade and retaliation from farmers because of crop use (Fuentes, 2006).

Our data corroborate other studies suggesting that both the Amazon and the Atlantic Forest will suffer significant biodiversity losses as a result of the combined effect of deforestation and climate change (Pires \& Costa, 2013; Bellard 
et al., 2014). In the Amazon, deforestation can alter the balance of the forest and transform it into a savannah environment (Costa \& Pires, 2010). Future climate change projections indicate a $20 \%$ increase in aridity, both for the Amazon rainforest and for the north-east of Brazil (Franchito et al., 2014), and an increase in temperature (Marengo et al., 2017). Biodiversity hotspots, such as the Cerrado and the Atlantic Forest, are predicted to be adversely affected by future climate change and to lose c. $25 \%$ of their endemic species (Bellard et al., 2014) because they are projected to become arid lands (Costa \& Pires, 2010; Franchito et al., 2014). It is believed that there will be changes in land use because of the projected decrease in herbaceous vegetation in the Cerrado and an increase in the extent of fragmentation and conversion to pasture in the Atlantic Forest (Bellard et al., 2014). Changes in spatial configuration and habitat quality may affect the distribution and density of primate species (Estrada et al., 2017), as well as the quantity and quality of food resources available to them (Dunn et al., 2009; Morellato et al., 2016).

To suggest important areas for conservation action, we identified protected areas that will maintain climate suitability in the future and may serve as a refuge for the target species. These areas were well represented in the areas suitable for S. libidinosus, but much less so in the areas suitable for A. belzebul and S. flavius. This indicates the importance of expanding or creating new protected areas for the latter two species, especially in the north-east Atlantic Forest. Although the overall percentage of protected areas affected by urban settlements was relatively low in our study (c. 14\%), a larger proportion of the areas suitable for S. flavius was affected by human settlements (c. 33\%). Human settlements close to areas suitable for these primates may result in hunting, but no data are available on current hunting pressure on S. flavius. Overexploitation has already eradicated several primate populations in Brazil, including populations of capuchin monkeys (Estrada et al., 2018). Strengthening environmental policies and enforcing laws is key to preventing hunting and further deforestation (Brancalion et al., 2016; Estrada et al., 2018).

Our study highlights concern regarding the conservation of Neotropical primates in general. We provide important information for the conservation of three primate species, two of which are part of the Brazilian Action Plan for the Conservation of Primates in Northeast Brazil. Although the three target species inhabit areas considered to be of global conservation importance (Brooks et al., 2006), the areas predicted to be suitable for these species are mostly outside protected areas and have low forest cover, especially in the Atlantic Forest. The Brazilian government has designated priority areas for conservation, but these are not sufficient to maintain the primate populations we have studied. By determining suitable areas for the occurrence of the target species under present and future conditions we have identified areas where conservation efforts should focus, to reduce habitat destruction and fragmentation. Creating and maintaining protected areas could help to preserve forested areas and contribute to the survival of these species.

Our models show that future climate change could lead to substantial range losses for the three primate species. This is of concern as these changes can affect the establishment of populations and their ability to survive in these areas in the long term. Our findings will facilitate assessment of the conservation status of each species and the establishment of goals in action plans for the conservation of other primate species inhabiting the same regions. We will share our findings and recommendations with key stakeholders such as the Centro Nacional de Pesquisa e Conservação de Primatas Brasileiros from the Chico Mendes Institute for Biodiversity Conservation, an administrative arm responsible for primate conservation action plans in Brazil. The sharing of our impartial scientific study may help such institutions plan future conservation actions, considering that the current Brazilian government is weakening environmental laws, leading to further deforestation, fragmentation and destruction of wildlife habitats in the country (Ferrante \& Fearnside, 2019).

Acknowledgements We thank Felipe França, José da Silva, Silvanete da Silva, Antônio Alencar Sampaio, Guga do Pinheiro, João da Silva and Yuri Marinho for assistance with fieldwork, Agência Estadual de Meio Ambiente in the Pimenteira State Park, the Parnamirim Irrigated Agriculture Station-UFRPE and the Programa de Pós-graduação em Biologia Animal (Graduate Programme in Animal Biology) for logistical support. We thank Enrico Bernard, Maria Adelia Oliveira and João Lucas Feitosa for fruitful discussions on earlier stages of this study. We acknowledge funding to BLCM from Fundação de Amparo a Ciência e Tecnologia do Estado de Pernambuco (FACEPE; grant number: IBPG-1013-2.04/14) and Coordination for the Improvement of Higher Education Personal (CAPES; grant number: PDSE 88881.134891/ 2016-01); to JPS-A from CAPES (grant number: 527091) and FACEPE (grant numbers: BCT-0025-2.05/17; BFP0149-2.05/10); to OR through a Natural Environment Research Council Independent Research Fellowship (NE/M018660/1). This study is a new contribution from the blonde capuchin research and conservation project supported by the Mohamed bin Zayed Species Conservation Fund, Margot Marsh Biodiversity Foundation, Rufford Small Grant Foundation, FACEPE (grant numbers: APQ-1534-2.04/10; APQ-0143-2.04/14; BFT-01602.04/17; BFT-0014-2.05/20) and Brazilian National Council for Scientific and Technological Development (CNPq; grant numbers: Universal 445071/2014-1; Pq2 309256/2019-4).

Author contributions Study design: BM, BB; fieldwork: BM; data analysis and writing: all authors.

\section{Conflicts of interest None.}

Ethical standards This research abides by the Oryx guidelines on ethical standards and was carried out in compliance with Brazilian law (fieldwork licence: SISBIO/ICMBio-52404-1; license for interviews: Plataforma Brasil-CAAE-49198215.3.0000.5208/Approval1.266.360). 


\section{References}

Bellard, C., Leclerc, C., Leroy, B., Bakkenes, M., Veloz, S., Thuiller, W. \& Courchamp, F. (2014) Vulnerability of biodiversity hotspots to global change. Global Ecology and Biogeography, 23, 1376-1386.

Beuchle, R., Grecchi, R.C., Shimabukuro, Y.E., Seliger, R., Eva, H.D., SANo, E. \& AChARD, F. (2015) Land cover changes in the Brazilian Cerrado and Caatinga biomes from 1990 to 2010 based on a systematic remote sensing sampling approach. Applied Geography, $58,116-127$.

Bezanson, M. \& McNamara, A. (2019) The what and where of primate field research may be failing primate conservation. Evolutionary Anthropology: Issues, News, and Reviews, $28,166-178$

Bezerra, B.M., Bastos, M., Souto, A. \& Jones, G. (2014) Camera trap observations of nonhabituated Critically Endangered wild blonde capuchins, Sapajus flavius (formerly Cebus flavius). International Journal of Primatology, 35, 895-907.

Brooks, T.M., Mittermeier, R.A., Da Fonseca, G.A.B., Gerlach, J., Hoffmann, M., Lamoreux, J.F. et al. (2006) Global biodiversity conservation priorities. Science, 313, 58-61.

Brown, J.L. (2014) SDMtoolbox: a python-based GIS toolkit for landscape genetic, biogeographic and species distribution model analyses. Methods in Ecology and Evolution, 5, 694-70o.

Brancalion, L.C., Garcia, R., Loyola, R.D., Rodrigues, R.R., Pillar, V.D. \& Lewinsohn, T.M. (2016) A critical analysis of the Native Vegetation Protection Law of Brazil (2012): updates and ongoing initiatives. Natureza \& Conservação, 14, 1-15.

Canale, G.R., Kierulff, M.C.M. \& Chivers, D.J. (2013) A Critically Endangered capuchin monkey (Sapajus xanthosternos) living in a highly fragmented hotspot. In Primates in Fragments. Developments in Primatology: Progress and Prospects (eds L. Marsh \& C. Chapman), pp. 299-311. Springer, New York, USA.

Costa, M.H. \& Pires, G.F. (2010) Effects of Amazon and central Brazil deforestation scenarios on the duration of the dry season in the arc of deforestation. International Journal of Climatology, 30, 1970-1979.

Costa-Araújo, R., Melo, F.R., Canale, G.R., HernándezRangel, S.M., Messias, M.R., Rossi, R.V. et al. (2019) The Munduruku marmoset: a new monkey species from southern Amazonia. PeerJ, 7, e7019.

Cowles, J., Boldgiv, B., Liancourt, P., Petraitis, P.S. \& Casper, B.B. (2018) Effects of increased temperature on plant communities depend on landscape location and precipitation. Ecology and Evolution, 8, 5267-5278.

de Souza Lins, P.G.A. \& Ferreira, R.G. (2019) Competition during sugarcane crop raiding by blond capuchin monkeys (Sapajus flavius). Primates, 6o, 81-91.

DIVA-GIS (2011) Free Spatial Data - Country Level - Elevation. divagis.org/data [accessed March 2018].

Dunn, J.C., Cristóbal-Azkarate, J. \& Vea, J. (2009) Differences in diet and activity pattern between two groups of Alouatta palliata associated with the availability of big trees and fruit of top food taxa. American Journal Primatology, 71, 654-662.

Elith, J. \& Leathwick, J.R. (2009) Species distribution models: ecological explanation and prediction across space and time. Annual Review of Ecology, Evolution and Systematics, 40, 77-697.

El-Keblawy, A., Abdelfattah, M.A. \& Khedr, A. (2015) Relationships between landforms, soil characteristics and dominant xerophytes in the hyper-arid northern United Arab Emirates. Journal of Arid Environments 117, 28-36.

Estrada, A., Garber, P.A., Rylands, A.B., Roos, C., Fernandez-Duque, E. \& Di Fiore, A. (2017) Impending extinction crisis of the world's primates: why primates matter. Science Advances, 3, e1600946.

Estrada, R.A., Garber, P.A., Mittermeier, R.A., Wich, S., Gouveia, S., Dobrovolski, R. et al. (2018) Primates in peril: the significance of Brazil, Madagascar, Indonesia and the Democratic Republic of the Congo for global primate conservation. PeerJ, 6, e4869.

Ferrante, L. \& Fearnside, P.M. (2019) Brazil's new president and 'ruralists' threaten Amazonia's environment, traditional peoples and the global climate. Environmental Conservation, 46, 261-263.

Flato, G., Marotzke, J., Abiodun, B., Braconnot, P., Chou, S.C., Collins, W. et al. (2013) Evaluation of climate models. In Climate Change 2013: The Physical Science Basis. Contribution of Working Group I to the Fifth Assessment Report of the Intergovernmental Panel on Climate Change (eds T.F. Stocker, D. Qin, G.-K. Plattner, M. Tignor, S.K. Allen, J. Boschung, A. Nauels, Y. Xia, V. Bex \& P.M. Midgley), pp. 741-866. Cambridge University Press, Cambridge, UK and New York, USA.

Franchito, S.H., Fernandez, J.P.R. \& Pareja, D. (2014) Surrogate climate change scenario and projections with a regional climate model: impact on the aridity in South America. American Journal of Climate Change, 3, 474-489.

Freire-Filho, R., Pinto, T. \& Bezerra, B. (2018) Using local ecological knowledge to access the distribution of Endangered Caatinga howler monkey (Alouatta ululata). Ethnobiology and Conservation, 7, 10.

Fuentes, A. (2006) Human-Nonhuman primate interconnections and their relevance to anthropology. Ecological and Environmental Anthropology, 2, 1-11.

Global Biodiversity Information Facility (2017) Free and Open Access to Biodiversity Data. GBIF Secretariat, Copenhagen, Denmark. gbif.org [accessed April 2020].

Geldmann, J., Barnes, M., Coad, L., Craigie, I.D., Hockings, M. \& BURGESS, N.D. (2013) Effectiveness of terrestrial protected areas in reducing habitat loss and population declines. Biological Conservation, 161, 230-238.

Gray, C.L., Hill, S.L.L., Newbold, T., Hudson, L.N., BÖrger, L., Contu, S. et al. (2016) Local biodiversity is higher inside than outside terrestrial protected areas worldwide. Nature Communications, 7, 12306.

Hijmans, R.J., Cameron, S.E., Parra, J.L., Jones, P.G. \& Jarvis, A. (2005) Very high resolution interpolated climate surfaces for global land areas. International Journal Climatology, 25, 1965-1978.

Hunke, P., Mueller, E.N., Schröder, B. \& Zeilhofer, P. (2014) The Brazilian Cerrado: assessment of water and soil degradation in catchments under intensive agricultural use. Ecohydrology: Ecosystems, Land and Water Process Interactions, Ecohydrogeomorphology, 8, 1154-1180.

ibGE (Instituto Brasileiro de Geografia e Estatísticas) (2017) Mudanças na Cobertura e Uso da Terra do Brasil 20oo-2010 2012-2014. Ministério de Planejamento, Orçamento e Gestão, Rio de Janeiro, Brazil.

iCmbio (Instituto Chico Mendes de Conservacẽo da Biodiversidade) (2016) Listas das Espécies da Fauna Brasileira Ameaçadas de Extinção Vigentes. icmbio.gov.br/portal/ faunabrasileira/lista-de-especies [accessed 14 August 2016].

iCMBio (Instituto Chico Mendes de Conservação da Biodiversidade) (2017) Unidades de Conservação Federais. icmbio. gov.br/portal/geoprocessamento1 [accessed 11 December 2017].

iCMBio (Instituto Chico Mendes de Conservação da Biodiversidade)-CPB (Centro Nacional de Pesquisa e Conservação de Primatas) (2018) Plano de Ação Nacional para Conservação de Primatas do Nordeste. Portaria no. 242, de 27 de março de 2018. icmbio.gov.br/portal/faunabrasileira/ 
plano-de-acao-nacional-lista/865-pan-primatas-do-nordeste [accessed 5 February 2018].

INPE (Instituto Nacional de Pesquisas Espaciais) (2001) Variáveis Ambientais para Modelagem de Distribuição de Espécies. dpi.inpe.br/ambdata/mapa_solos.php [accessed November 2018].

IUCN (2020) The Red List of Threatened Species. Version 2020-2. iucnredlist.org [accessed 28 August 2020].

Liu, C., White, M. \& Newell, G. (2013) Selecting thresholds for the prediction of species occurrence with presence-only data. Journal of Biogeography, 40, 778-789.

Mandujano, S., Escobedo-Morales, L.A. \& Palacios-Silva, R. (2004) Movements of Alouatta palliata among forest fragments in Los Tuxtla, México. Neotropical Primates, 12, 126-131.

Marengo, J.A., Torres, R.R. \& Alves, L.M. (2017) Drought in Northeast Brazil-past, present, and future. Theoretical and Applied Climatology, 129, 1189-1200.

Martins, A.B., Valença-Montenegro, M.M., Fialho, M.S., Laroque, P.O. \& Di Fiore, A. (2016) Range expansion and observation of tool use by blonde capuchins, Sapajus flavius, in the Caatinga biome of Brazil. Presented at Meeting of the International Primatological Society and the American Society of Primatologists, 21-27 August, 2016, Chicago, USA.

Medeiros, K., Bastos, M., Jones, G. \& Bezerra, B. (2019) Behavior, diet, and habitat use by blonde capuchin monkeys (Sapajus flavius) in a coastal area prone to flooding: direct observations and camera trapping. International Journal of Primatology, 40, 511-531.

Mittermeier, R.A., Rylands, A.B., Schwitzer, C., Taylor, L.A., Chiozza, F. \& Williamson, E.A. (eds) (2012) Primates in Peril: The World's 25 Most Endangered Primates 2010-2012. IUCN/SSC Primate Specialist Group, International Primatological Society and Conservation International, Arlington, USA.

MmA (Ministério do Meio Ambiente) (2016) $5^{\circ}$ Relatório Nacional para a Convenção sobre Diversidade Biológica. Série Biodiversidade, v. 5o. Brasília, Brasil: Ministério do Meio Ambiente, Brasilia, Brazil.

MmA (Ministério do Meio Ambiente) (2003) World Wildlife Fund Terrestrial Ecoregions. mapas.mma.gov.br/izgeo/ datadownload.htm [accessed March 2017].

ma (Ministério do Meio Ambiente) (2018a) Áreas Prioritárias para a Conservação da Biodiversidade. areasprioritarias.mma.gov. br/oque-e [accessed 15 June 2018].

MMA (Ministério do Meio Ambiente) (2018b) Cadastro Nacional de Unidades de Conservação. mma.gov.br/ areas-protegidas/cadastro-nacional-de-ucs [accessed 15 June 2018].

Morellato, L.P.C., Alberton, B., Alvarado, S.T., Borges, B., Buisson, E., Gabriela, M. et al. (2016) Linking plant phenology to conservation biology. Biology Conservation, 195, 60-72.

Muscarella, R., Galante, P.J., Soley-Guardia, M., Boria, R.A., Kass, J.M., URiarte, M. \& Anderson, R.P. (2014) ENMeval: an $R$ package for conducting spatially independent evaluations and estimating optimal model complexity for Maxent ecological niche models. Methods in Ecology and Evolution, 5, 1198-1205.

Nascimento, R.A., Schiavetti, A. \& Montaño, R.A.M. (2013) An assessment of illegal capuchin monkey trade in Bahia State, Brazil. Neotropical Biology and Conservation, 8, 79-87.

Oliveira, A.P.C. \& Bernard, E. (2017) The financial needs vs. the realities of in situ conservation: an analysis of federal funding for protected areas in Brazil's Caatinga. Biotropica, 49, 745-752.

Phillips, S.J., Anderson, R.P. \& Schapire, R.E. (2006) Maximum entropy modelling of species geographic distributions. Ecological Modelling, 190, 231-259.

Pinto, A.C.B., Azevedo-Ramos, C. \& de Carvalho, Jr, O. (2013) Activity patterns and diet of the howler monkey Alouatta belzebul in areas of logged and unlogged forest in eastern Amazonia. Animal Biodiversity and Conservation, 26, 39-49.

Pires, G.F. \& Costa, M.H. (2013) Deforestation causes different subregional effects on the Amazon bioclimatic equilibrium. Geophysical Research Letters, 40, 3618-3623.

Portillo-Quintero, C.A. \& SÁnchez-Azofeifa, G.A. (2010) Extent and conservation of tropical dry forests in the Americas. Biological Conservation, 143, 144-155.

Prado, D.E. (2003) As caatingas da América do Sul. In Ecologia e Conservação da Caatinga (eds I.R. Leal, M. Tabarelli \& J.M.C. Silva), pp. 3-73. Universitária da UFPE, Recife, Brazil.

Raes, N. \& TER Steege, H. (2007) A null-model for significance testing of presence-only species distribution models. Ecography, 30, 727-736.

Ratter, J.A., Ribeiro, J.F. \& Bridgewater, S. (1997) The Brazilian Cerrado vegetation and threats to its biodiversity. Annals of Botany, 8o, 223-230.

R Core Team (2017) A Language and Environment for Statistical Computing. R Foundation for Statistical Computin, Vienna, Austria. R-project.org [accessed 16 March 2020].

Rêgo, G.M. \& Hoeflich, V.A. (2001) Contribuição da Pesquisa Florestal para um Ecossistema em Extinção: Floresta Atlântica do Nordeste do Brasil. Embrapa Tabuleiros Costeiros, Aracaju, Brazil.

Renner, I.W., Elith, J., Baddeley, A., Fithian, W., Hastie, T., Phillips, S.J. et al. (2015) Point process models for presence-only analysis. Methods in Ecology and Evolution, 6, 366-379.

Ribeiro, M.C., Martensen, A.C., Metzger, J.P., Tabarelli, M., Scarano, F. \& Fortin, M.-J. (2011) The Brazilian Atlantic Forest: a shrinking biodiversity hotspot. In Biodiversity Hotspots (eds F.E. Zachos \& J.C. Habel), pp. 405-433. Springer, Berlin and Heidelberg, Germany.

Rodrigues, A.S.L., Andelman, S.J., Bakarr, M.I., Boitani, L., Brooks, T.M., Cowling, R.M. et al. (2004) Effectiveness of the global protected area network in representing species diversity. Nature, 428, 640-643.

Rylands, A.B. \& Kierulff, M.C.M. (2015) Sapajus libidinosus. In The IUCN Red List of Threatened Species 2015: e.T136346A70613080. dx.doi.org/10.2305/IUCN.UK.2015-1.RLTS.T136346A70613080.en [accessed 5 February 2019].

Saout, S.L., Hoffmann, M., Shi, Y., Hughes, A., Bernard, C., Brooks, T.M. et al. (2013) Protected areas and effective biodiversity conservation. Science, 342, 803-805.

Schulze, K., Knighs, K., Coad, L., Geldmann, J., Leverington, F., EAssom, A. et al. (2018) An assessment of threats to terrestrial protected areas. Conservation Letters, 11, e12435.

Shi-Kui, D., Weia, S., Xu-Kunb, S., Yongc, Z., Shuaia, L. XiaoxaIA, G. et al. (2019) The impacts of geographic, soil and climatic factors on plant diversity, biomass and their relationships of the alpine dry ecosystems: cases from the Aerjin Mountain Nature Reserve, China. Ecological Engineering, $127,170-177$

Silva, E.A. \& Fialho, M.S. (2013) Geoprocessamento Aplicado ao Plano de Ação Nacional para a Conservação dos Primatas do Nordeste-PAN: Identificação, Monitoramento e Manejo de Áreas Estratégicas à Conectividade Funcional das Espécies-Alvo. Centro Nacional de Pesquisa e Conservação de Primatas Brasileiros-CPB/ ICMBio, João Pessoa, Brazil.

SPECIESLINK (2017) speciesLink: a Distributed Information System that Integrates Primary Data from Biological Collections. splink.cria.org.br [accessed April 202O].

Schwitzer, C., Mittermeier, R.A., Rylands, A.B., Chiozza, F., Williamson, E.A., Byler, D. et al. (eds) (2019) Primates in Peril: The World's 25 Most Endangered Primates 2018-2020. IUCN SSC Primate Specialist Group, International Primatological Society, 
Bristol Zoological Society, and Global Wildlife Conservation, Washington, DC, USA.

Souto, W.M.S., Barboza, R.R.D., Fernandes-Ferreira, H., Júnior, A.J.C.M., Monteiro, J.M., Abi-Chacra, E.A. \& Alves, R.R.N. (2018) Zootherapeutic uses of wildmeat and associated products in the semiarid region of Brazil: general aspects and challenges for conservation. Journal of Ethnobiology and Ethnomedicine 14, 60.

Souza-Alves, J.P., Mourthe, I., Hilário, R.R., Bicca-Marques, J.C., RehG, J., Gestich, C.C. et al. (2019) Terrestrial behavior in titi monkeys (Callicebus, Cheracebus, and Plecturocebus): potential correlates, patterns, and differences between genera. International Journal of Primatology, 40, 553-572.

Strassburg, B.B.N., Brooks, T., Feltran-Barbieri, R., Iribarrem, A., Crouzeilles, R., Loyola, R. et al. (2017) Moment of truth for the Cerrado hotspot. Nature Ecology \& Evolution, 1, 0099.

Tabarelli, M., Aguiar, A.V., Ribeiro, M.C., Metzger, J.P. \& Peres, C.A. (2010) Prospects for biodiversity conservation in the Atlantic Forest: lessons from aging human-modified landscapes. Biological Conservation, 143, 2328-2340.

Titeux, N., Henle, K., Mihoub, J.B., Regos, A., Geijzendorffer, I.R. \& CrameR, W. et al. (2017) Global scenarios for biodiversity need to better integrate climate and land use change. Diversity and Distributions, 23, 1231-1234.

Torres Junior, E.U., Valença-Montenegro, M.M. \& de Castro, C.S.S. (2016) Local ecological knowledge about endangered primates in a rural community in Paraíba, Brazil. Folia Primatologica, $87,262-277$.

Valença Montenegro, M., Bezerra, B., Fialho, M., Jerusalinsky, L., Lynch Alfaro, J. \& Martins, A.B. (2020) Sapajus flavius. In The IUCN Red List of Threatened Species 2020: e.T136253A70612866. dx.doi.org/10.2305/IUCN.UK.2020-2.RLTS. T136253A70612866.en [accessed 28 August 2020].

Veiga, L.M., Kierulff, C. \& De Oliveira, M.M. (2008) Alouatta belzebul. In The IUCN Red List of Threatened Species 2008: e.T39957A10298051. dx.doi.org/10.2305/IUCN.UK.2008.RLTS. T39957A10298051.en [accessed 5 February 2019].

Villar, J.C.E., Rnchail, J., Guyot, J.L., Cochonneau, G., Naziano, F., Lavado, W., De Oliveira, E. et al. (2009) Spatio-temporal rainfall variability in the Amazon basin countries (Brazil, Peru, Bolivia, Colombia, and Ecuador). International Journal Climatology, 29, 1574-1594.

WARREN, D.L., GLOR, R.E. \& TuRELLI, M. (2010) ENMTools: a toolbox for comparative studies of environmental niche models. Ecography, $33,607-611$.

Wayne, G.P. (2013) The Beginner's Guide to Representative Concentration Pathways. Skeptical Science. skepticalscience.com/ rcp.php [accessed 16 March 2020].

Zwiener, V.P., Lira-Noriega, A., Grady, C.J., Padial, A.A. \& Vitule, J.R.S. (2018) Climate change as a driver of biotic homogenization of woody plants in the Atlantic Forest. Global Ecology and Biogeography, 27, 298-309. 